\title{
Method to Determine Appropriate Source Models of Large Earthquakes Including Tsunami Earthquakes for Tsunami Early Warning in Central America
}

\author{
Yuichiro Tanioka, ${ }^{1}$ (D) Greyving Jose Arguello Miranda, ${ }^{2}$ Aditya Riadi Gusman, ${ }^{3}$ and Yushiro FujiI ${ }^{4}$
}

\begin{abstract}
Large earthquakes, such as the Mw 7.71992 Nicaragua earthquake, have occurred off the Pacific coasts of El Salvador and Nicaragua in Central America and have generated distractive tsunamis along these coasts. It is necessary to determine appropriate fault models before large tsunamis hit the coast. In this study, first, fault parameters were estimated from the W-phase inversion, and then an appropriate fault model was determined from the fault parameters and scaling relationships with a depth dependent rigidity. The method was tested for four large earthquakes, the 1992 Nicaragua tsunami earthquake (Mw7.7), the 2001 El Salvador earthquake (Mw7.7), the 2004 El Astillero earthquake (Mw7.0), and the 2012 El Salvador-Nicaragua earthquake (Mw7.3), which occurred off El Salvador and Nicaragua in Central America. The tsunami numerical simulations were carried out from the determined fault models. We found that the observed tsunami heights, run-up heights, and inundation areas were reasonably well explained by the computed ones. Therefore, our method for tsunami early warning purpose should work to estimate a fault model which reproduces tsunami heights near the coast of El Salvador and Nicaragua due to large earthquakes in the subduction zone.
\end{abstract}

Key words: Tsunami early warning, nicaragua tsunami, tsunami simulation.

\section{Introduction}

The 1992 Nicaragua earthquake occurred off the Pacific coast of Central America and generated a much larger tsunami than expected from its surface wave magnitude of $M_{\mathrm{s}} 7.2$; so the earthquake is

1 Institute of Seismology and Volcanology, Hokkaido University, N10W8 Kita-ku, Sapporo, Hokkaido 060-0810, Japan. E-mail: tanioka@sci.hokudai.ac.jp

2 Nicaraguan Institute of Territorial Studies, Managua, Nicaragua.

3 Earthquake Research Institute, University of Tokyo, Tokyo, Japan.

4 International Institute of Seismology and Earthquake Engineering, Building Research Institute, Tsukuba, Japan. classified as a 'tsunami earthquake' (Satake et al. 1993). Seismological analysis of the earthquake (Ide et al. 1993, Kanamori and Kikuchi 1993) and tsunami waveform analysis (Satake 1994) showed that the seismic moment $M_{0}$ is $3-4 \times 10^{20} \mathrm{Nm}$ (Mw = 7.6-7.7). Imamura et al. (1993) estimated the fault model from the tsunami run-up heights along the coast using tsunami numerical simulation and found that the slip amount should be 5.6-10 times larger than that estimated from the seismic data. Those results indicated that it was difficult to estimate an appropriate source model from the seismic wave analysis to forecast the tsunami heights along the coast of Nicaragua. Development of a method to quickly estimate an appropriate source model for both tsunami earthquakes and typical large underthrust earthquakes is necessary for improving tsunami early warning in Central America.

Recently, Gusman and Tanioka (2014) developed a method to estimate an appropriate source model for tsunami early warning using the results from W-phase inversions (Kanamori and Rivera 2008) of broadband seismograms. They applied their method to the 2011 Tohoku-oki tsunami and found that the observed tsunami run-up heights are well explained by the run-up heights numerically computed from the source model estimated by the $\mathrm{W}$-phase inversion of the first 10 min of seismic waveform data.

In this paper, we improve the method developed by Gusman and Tanioka (2014), so the method can be applied not only for typical large underthrust earthquakes but also for tsunami earthquakes. The method was tested for the 1992 Nicaragua tsunami earthquake (Mw7.6), the 2001 El Salvador earthquake (Mw7.7), the 2004 Astillero earthquake (Mw6.9), and the 2012 El Salvador-Nicaragua earthquake (Mw7.3) in Fig. 1. 


\section{Data}

Low-frequency broadband seismic records from the database at the Incorporated Research Institute for Seismology (IRIS) catalog are downloaded. The vertical components for stations located between epicentral distance ranges $0^{\circ}-90^{\circ}$ are used for the $\mathrm{W}$-phase inversion. The data were obtained in networks, NU (Nicaraguan seismic Network), IU (IRIS/ USGS), II (IRIS/IDA), GNS, and GE (GEOFON).

The General Bathymetry Chart of the Oceans (GEBCO) dataset of 30 arcseconds grid spacing was used for the tsunami numerical simulation. The topography data, Shuttle Radar Topography Mission (SRTM) with a resolution of 3 arcseconds, are used for the tsunami inundation simulation.

Tsunami field survey of tsunami run-up heights and inundation area was conducted immediately after the 1992 Nicaragua tsunami earthquake by Abe et al. (1993). Tsunami field survey was also conducted for the 2012 El Salvador-Nicaragua tsunami by Borrero et al. (2014). For 2001 El Salvador earthquake, a small tsunami of about $0.25 \mathrm{~m}$ in El Salvador was reported in the NOAA historical tsunami database. Those data are compared with those from a tsunami simulation to test our method.

\section{Method}

\subsection{W-Phase Inversion}

The $\mathrm{W}$ phase, a distinct long-period (100-1000 s) phase arrives before the $\mathrm{S}$ phase and can be used for rapid and robust determination of great earthquake source parameters (Kanamori and Rivera 2008; Duputel et al. 2011). This W-phase inversion algorithm is used to estimate the magnitudes, the centroid locations, the half durations, and the mechanisms of the four earthquakes, the 1992 Nicaragua tsunami earthquake (Mw7.6), the 2001 El Salvador earthquake (Mw7.7), the 2004 Astillero earthquake

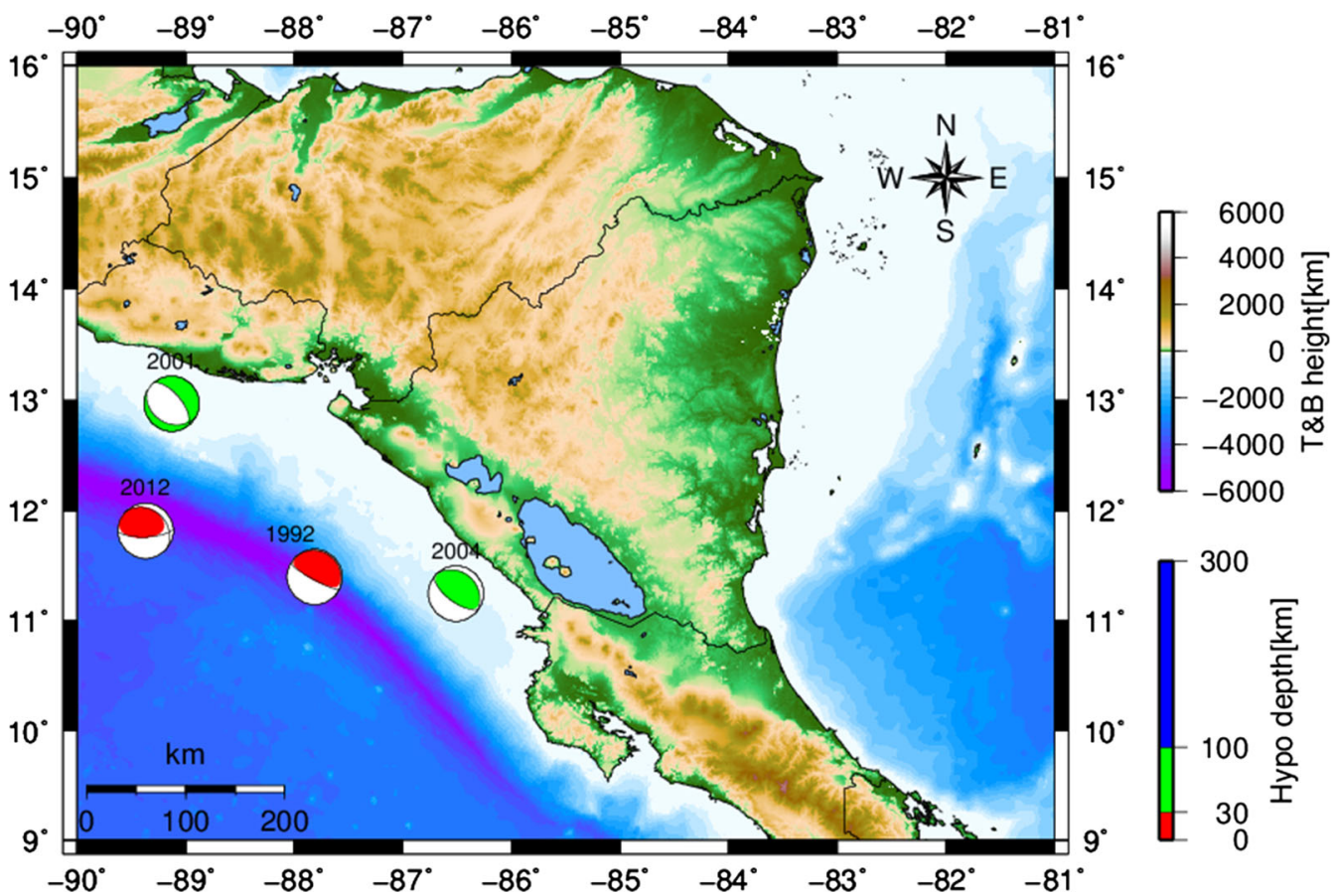

Figure 1

Bathymetry and topography in the study area and estimated mechanisms of four large earthquakes: the 1992 Nicaragua tsunami earthquake, the 2001 El Salvador earthquake, the 2004 Astillero earthquake, and the 2012 El Salvador-Nicaragua earthquake, which were tested to estimate appropriate source models for the tsunami early warning purpose 
(Mw6.9), and the 2012 El Salvador-Nicaragua earthquake (Mw7.3) in Fig. 1. Time domain deconvolution is used to retrieve displacement waveforms from the broadband seismograms. Then they are bandpass filtered between 0.00167 and $0.005 \mathrm{~Hz}$ for great earthquake $(M \geq 7.5)$ using fourth order of Butterworth filter. For large earthquake $(7.5>M>7.0)$, the displacement waveforms are bandpass filtered between 0.00167 and $0.01 \mathrm{~Hz}$. The time window (in seconds) used in the inversion is set between $\mathrm{P}$ wave arrival and that plus 15 times the distance (degree) between the epicenter and the station. For more details of the W-phase inversion method, see Kanamori and Rivera (2008) and Duputel et al. (2011, 2012).

\subsection{Scaling Relationships}

Scaling relationships are needed to estimate the width and length of the fault model from the earthquake's moment magnitude. Gusman and Tanioka (2014) used the magnitude (Mw) to source area (A) scaling relationship, $\mathrm{Mw}=4 / 3 \log A+3.03$, of Hanks and Bakun (2002). However, this scaling relationship is based predominantly on continental earthquakes. In this paper, the magnitude to fault length $(L) \quad$ scaling relationships, $\log L=-0.28+0.55 \mathrm{Mw}$ for thrust fault events or $\log L=-1.61+0.46 \mathrm{Mw}$ for normal fault events, from Blaser et al. (2010) are used because this scaling relationship is estimated for subduction zone earthquakes. The fault width $(W)$ is calculated using scaling relationships, $\log W=-1.8+0.45 \mathrm{Mw}$ for thrust fault events or $\log W=-1.08+0.34 \mathrm{Mw}$ for normal fault events, from Blaser et al. (2010). The center of the fault is located at the centroid of the $\mathrm{W}$-phase inversion. Then, a slip amount can be estimated from the rupture area and seismic moment by assuming the rigidity along the plate interface. Previous studies generally assumed a constant rigidity of $3-4 \times 10^{10} \mathrm{Nm}^{-2}$. However, Satake (1994) suggested that the 1992 Nicaragua tsunami earthquake occurred near the trench where the rigidity is $1 \times 10^{10} \mathrm{Nm}^{-2}$. Bilek and Lay (1999) studied the source duration of earthquakes and found a depth dependence to rigidity or stress drop. In this study, we decided to use the depth-dependent rigidity suggested

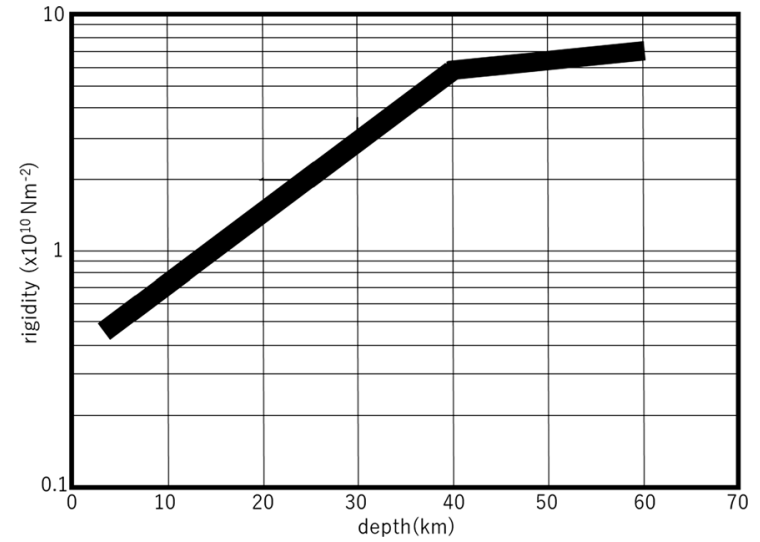

Figure 2

A depth-dependent rigidity curve used in this study. This relationship is obtained by simplifying the relationship suggested by Bilek and Lay (1999)

by Bilek and Lay (1999) and simplified it as shown in Fig. 2. The slip amount of the fault model is calculated using the rigidity obtained from the depth dependence relationship in Fig. 2. Here, the depth is the center of the fault model.

\subsection{Tsunami Numerical Simulation}

The vertical ocean bottom deformation due to an earthquake is computed from the fault model using the equations of Okada (1985). This vertical deformation is used as the tsunami initial surface deformation. The tsunami propagation is numerically computed using the non-linear shallow water equations solved by the finite difference scheme (Goto et al. 1997). Tsunami inundation is numerically computed using a moving boundary condition. Discharge across the boundary between two cells is calculated if the ground height in the dry cell is lower than the water level in the submerged cell; otherwise, discharge is considered to be zero (Imamura 1996). A Manning's roughness coefficient in the non-linear shallow water equations is assumed to be $0.025 \mathrm{~m}^{-1 /}$ 3 . Four nested grid systems are used for this tsunami simulation. For Region 1 (R1), the bathymetry GEBCO 30 arcseconds was resampled to make 1 min grid system. For Regions 2 and 3 (R2 and $\mathrm{R} 3$ ), it was interpolated to make $1 / 3^{\prime}$ (one-third minute) and $1 / 9^{\prime}$ (one-ninth minute) grid systems, respectively. For Region 4 (R4), the interpolated 
GEBCO 30 arcseconds bathymetry data are combined with Shuttle Radar Topography Mission (SRTM) 3 arcseconds topography data to make $1 / 27^{\prime}$ (one-twenty seventh minute) grid system. The SRTM 3 arcseconds topography data are the most critical data for the tsunami inundation simulation.

\section{The 1992 Nicaragua Tsunami Earthquake}

(Mw7.6)

On September 2, 1992, the Nicaragua earthquake generated a large tsunami that caused extensive damage along the Pacific coast of Nicaragua, including 170 casualties, despite its surface wave magnitude, $M_{\mathrm{s}}$ 7.2. Field survey of tsunami run-up heights (Abe et al. 1993; Satake et al. 1993) showed that the maximum tsunami run-up height was $9.9 \mathrm{~m}$ above mean sea level, although the maximum intensity in Modified Mercalli scale was only III. This weak intensity with a large tsunami indicates that this was an unusual 'tsunami earthquake' (Satake 1994). Global Centroid Moment Tensor (GCMT) catalog shows that the seismic moment of the earthquake is $3.4 \times 10^{20} \mathrm{Nm}$ (Mw7.6) with a thrust-type mechanism, a dip angle of $12^{\circ}$.

\subsection{W-Phase Inversion for the 1992 Nicaragua Earthquake}

The vertical components of ten broadband seismic records shown in Fig. 3 were used for performing the $\mathrm{W}$-phase inversion. The seismic data are bandpass filtered between 0.00167 and $0.005 \mathrm{~Hz}$. Because stations are located in the distance range from $0^{\circ}$ to $90^{\circ}$, at least $35 \mathrm{~min}$ of seismic records after the origin time are needed for the $\mathrm{W}$-phase inversion. The final solution of $\mathrm{W}$-phase inversion gives a seismic moment of $5.0 \times 10^{20} \mathrm{Nm}$ (Mw 7.73), a mechanism (strike $=315.8^{\circ}$, dip $=9.6^{\circ}$, rake $\left.=106.9^{\circ}\right)$, a centroid location (longitude $87.81^{\circ} \mathrm{W}$, latitude $11.40^{\circ} \mathrm{N}$ ), a centroid depth of $15.5 \mathrm{~km}$, and the half duration of $53 \mathrm{~s}$. This long rupture duration for the 1992 Nicaragua earthquake is consistent with the previous studies (Ide et al. 1993; Kanamori and Kikuchi 1993).

\subsection{Tsunami Simulation for the 1992 Nicaragua Earthquake}

The length, $100 \mathrm{~km}$, and the width, $52 \mathrm{~km}$, of the fault model are calculated from Mw7.7 using the scaling relationship of Blaser et al. (2010). The location of the fault model is shown in Fig. 3. The rigidity of $1.0 \times 10^{10} \mathrm{Nm}^{-2}$ is obtained from the
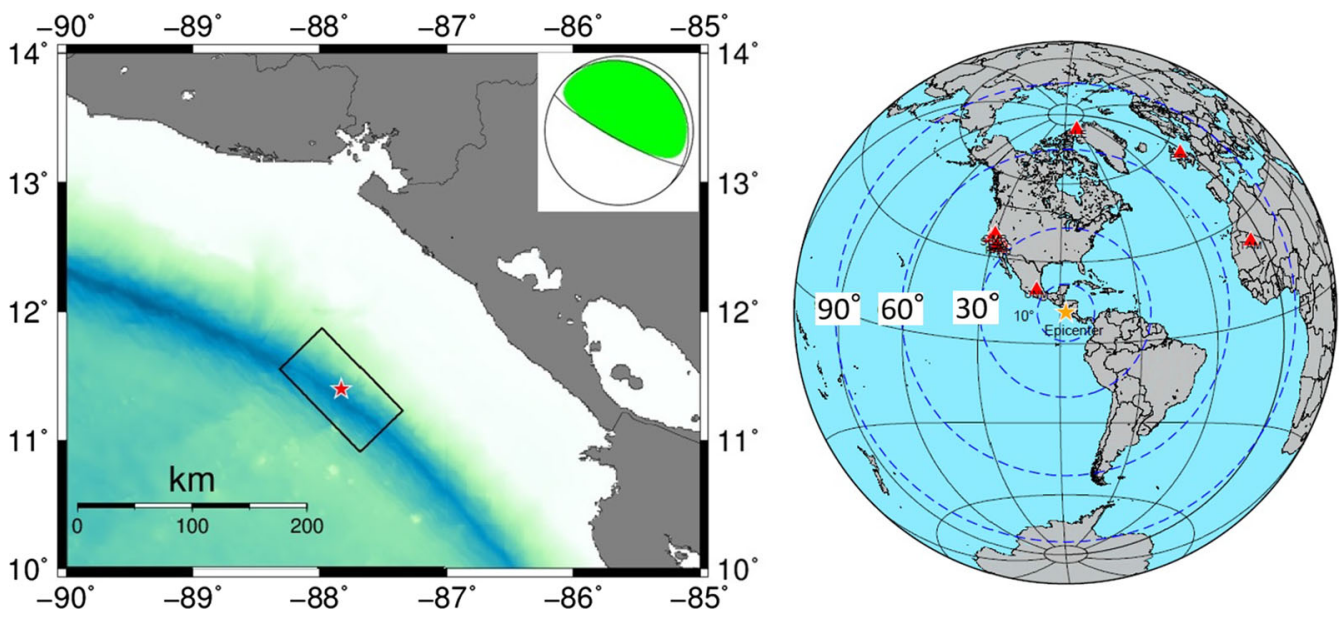

Figure 3

Left the fault model and the mechanism of the 1992 Nicaragua tsunami earthquake estimated from the results of W-phase inversion and scaling relationships. Right the station distribution; red triangles, used in W-phase inversion 


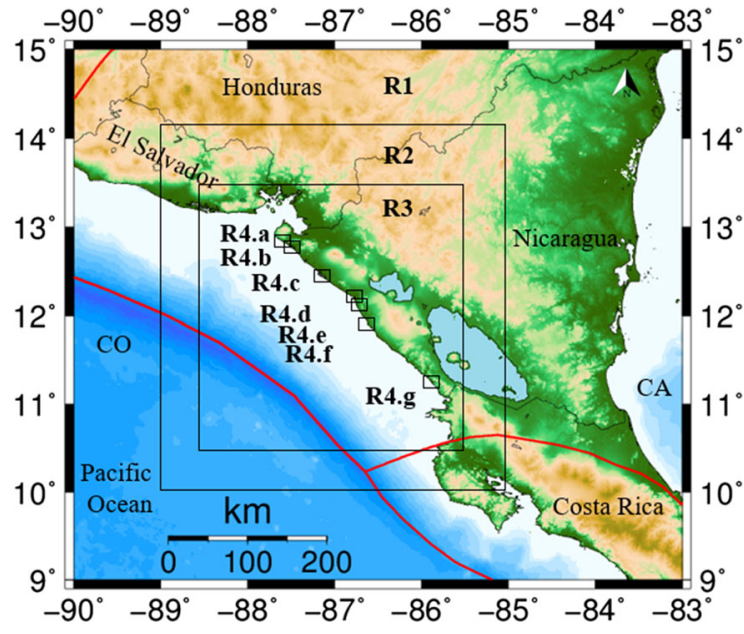

Figure 4

Four nested grid systems $(R 1, R 2, R 3$, and $R 4)$ for the tsunami numerical simulation of the 1992 Nicaragua tsunami. Seven areas were selected for tsunami run-up simulation grid systems, Mechapa (R4.a), Jiquililo (R4.b), Corinto (R4.c), Puerto Sandino (R4.d), El Transito (R4.e), Masachapa (R4.f), and San Juan del Sur (R4.g)

depth-dependent relation (Fig. 2) for the centroid depth of $15.5 \mathrm{~km}$. The slip amount is calculated to be $9.6 \mathrm{~m}$. Numerical computation of tsunami run-up was carried out for seven areas, Mechapa (R4.a), Jiquililo (R4.b), Corinto (R4.c), Puerto Sandino (R4.d), El Transito (R4.e), Masachapa (R4.f) and San Juan del Sur (R4.g) as shown in Fig. 4 where tsunami run-up heights were extensively surveyed by Abe et al. (1993). Four nested grid systems (R1, R2, R3, and R4 in Fig. 4) are used for this computation.

Mechapa $\left(12.83^{\circ} \mathrm{N}, 87.58^{\circ} \mathrm{W}\right)$ is located on the north Pacific coast of Nicaragua, R4.a in Fig. 4. In this town, tsunami heights between 3.9 and $4.1 \mathrm{~m}$ were observed (Abe et al. 1993). In our numerical calculation, the tsunami heights are between 3.7 and $4.4 \mathrm{~m}$, similar to those observed (Fig. 5a). The maximum inundation distance is computed to be about $200 \mathrm{~m}$ from the coastline. The computed inundation depths are around $0.2-1.5 \mathrm{~m}$. In this town, the houses are located about $100.0 \mathrm{~m}$ from the coast and between 4.0 and $9.0 \mathrm{~m}$ above mean sea level. No fatalities were reported in this town.

Jiquililo $\left(12.73^{\circ} \mathrm{N}, 87.44^{\circ} \mathrm{W}\right)$ is located in $\mathrm{R} 4 . \mathrm{b}$ in Fig. 4. In this town, tsunami heights between 2.1 and $2.5 \mathrm{~m}$ were observed (Abe et al. 1993). The tsunami height from the numerical calculation is $3.3 \mathrm{~m}$, similar to the observed ones (Fig. 5b). The maximum computed inundation distance is about $140 \mathrm{~m}$ from the coastline, in contrast to $175.0 \mathrm{~m}$ measured by the field survey (Abe et al. 1993). The computed inundation depths are about $1.0 \mathrm{~m}$. This town is located at about $60.0 \mathrm{~m}$ from the coast and between 1.0 and $6.0 \mathrm{~m}$ above mean sea level. No fatalities were reported in this town either.

Corinto $\left(12.49^{\circ} \mathrm{N}, 87.17^{\circ} \mathrm{W}\right)$ is a small town located in R4.c in Fig. 4. In this town, tsunami heights between 2.7 and $3.9 \mathrm{~m}$ were observed (Abe et al. 1993). Tsunami heights from the numerical calculation are in the range from 3.2 to $3.4 \mathrm{~m}$, similar to the observed heights (Fig. 5c). The maximum computed inundation distance is $150.0 \mathrm{~m}$ from the shoreline. The computed inundation depths are about 1.0-1.5 m. This town is located at about $50.0 \mathrm{~m}$ from the coast and between 1.0 and $8.0 \mathrm{~m}$ above mean sea level. Three people died in this town due to the tsunami.

Puerto Sandino $\left(12.19^{\circ} \mathrm{N}, 86.76^{\circ} \mathrm{W}\right)$ is located in R4.d in Fig. 4. In this town, tsunami heights between 3.5 and $3.7 \mathrm{~m}$ were observed (Abe et al. 1993). The tsunami heights from the numerical computation are between 6.4 and $7.0 \mathrm{~m}$, which are larger than the observed ones (Fig. 5d). The maximum computed inundation distance is about $340 \mathrm{~m}$ from the shoreline. The computed inundation depths are around $1.0-2.0 \mathrm{~m}$. Thirty-one people were injured in this town (Abe et al. 1993).

El Tránsito $\left(12.05^{\circ} \mathrm{N}, 86.70^{\circ} \mathrm{W}\right)$ is one of the most affected areas by this tsunami. In this town, tsunami heights between 6.4 and $9.9 \mathrm{~m}$ were observed (Abe et al. 1993). From the numerical computation, the tsunami heights are estimated to be between 8.1 and $8.9 \mathrm{~m}$, which is consistent with the observed ones (Fig. 5e). Detailed inundation area surveyed by Abe et al. (1993) is also consistent with the computed inundation area as shown in Fig. 5e. The maximum computed inundation distance is $6000.0 \mathrm{~m}$ from the shoreline. In total, there were 16 fatalities and 151 injured in this town (Abe et al. 1993).

Masachapa $\left(11.78^{\circ} \mathrm{N}, 86.51^{\circ} \mathrm{W}\right)$ is located in R4.f in Fig. 4. In this town, tsunami heights between 3.3 and $6.2 \mathrm{~m}$ were observed (Abe et al. 1993). From the numerical computation, the tsunami heights are estimated to be from 3.3 to $4.6 \mathrm{~m}$, which is consistent with the observed ones (Fig. 5f). The maximum inundation distance is calculated to be $670.0 \mathrm{~m}$ from 

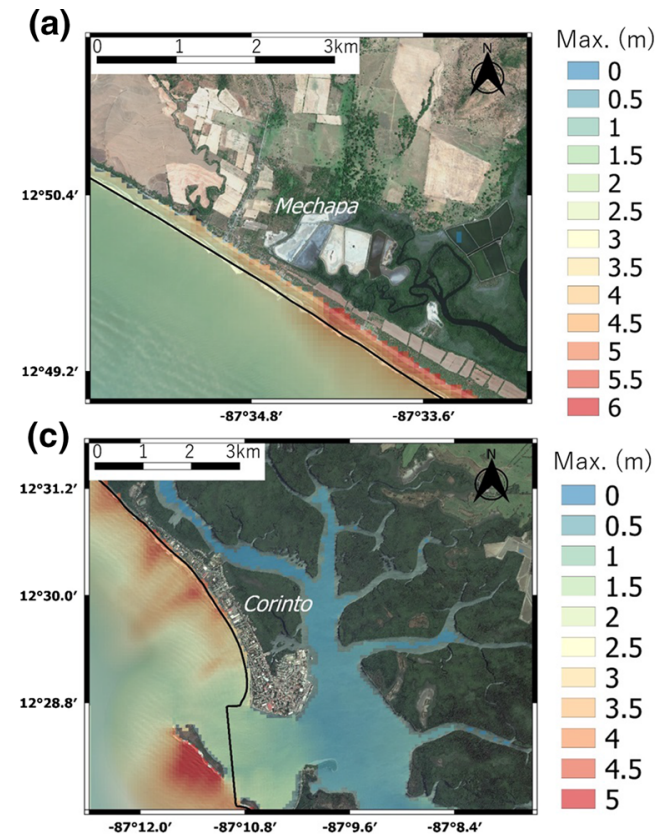
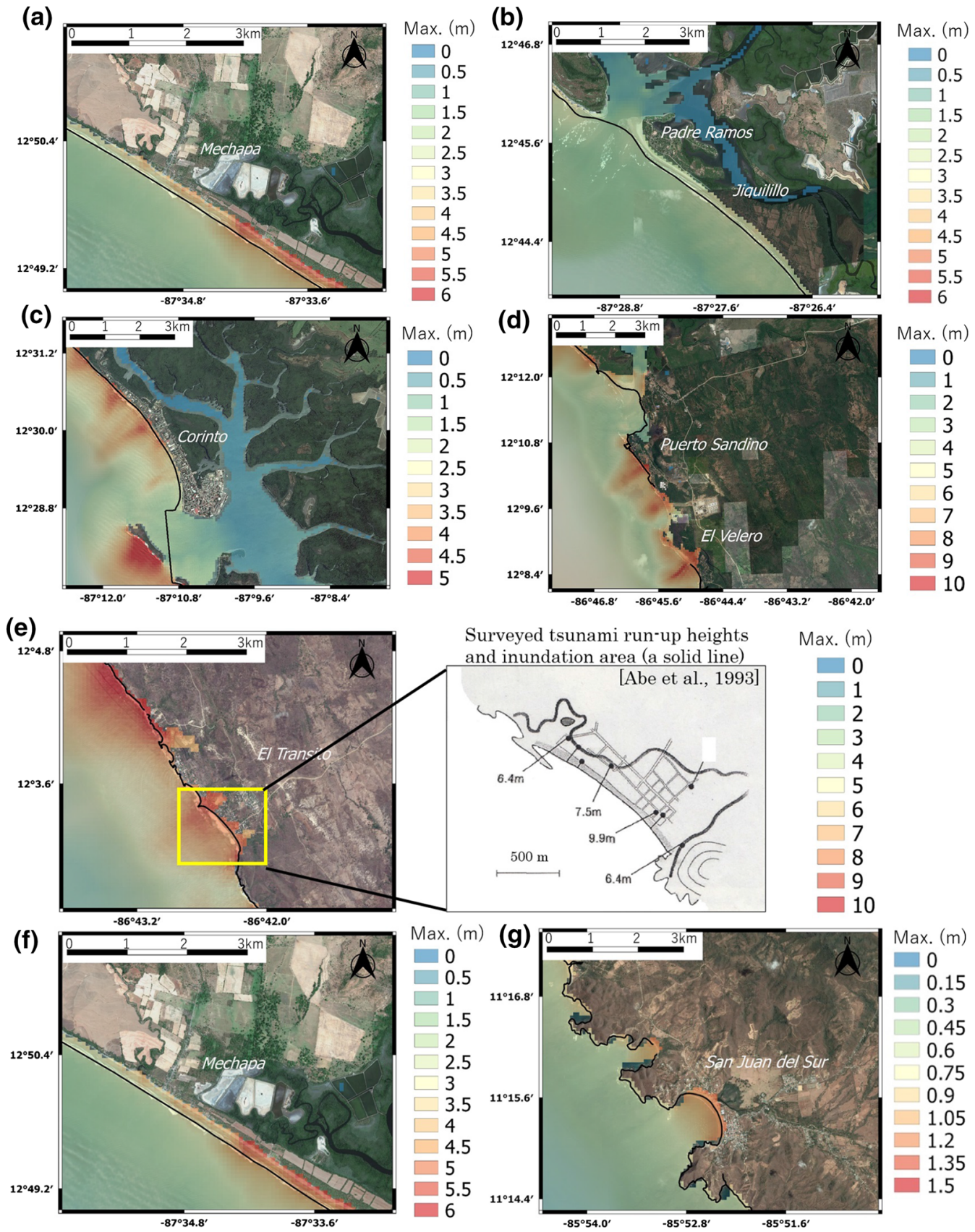

Figure 5

Maximum tsunami height distributions and tsunami inundation area at a Mechapa (R4.a in Fig. 4), b Jiquililo (R4.b in Fig. 4), c Corinto (R4.c in Fig. 4), d Puerto Sandino (R4.d in Fig. 4), e El Transito (R4.e in Fig. 4), f Masachapa (R4.f in Fig. 4), and g San Juan del Sur (R4.g in Fig. 4) computed from the fault model of the 1992 Nicaragua tsunami earthquake in Fig. 3. At El Transito (e), the maximum computed run-up heights and the computed inundation area are compared with the observed ones surveyed by Abe at al. (1993)

the coastline as shown in Fig. 5f. The computed inundation depths are about 1.0-2.0 m. In total, 19 fatalities in this town and its vicinity were reported (Abe et al. 1993).
San Juan del Sur $\left(11.251^{\circ} \mathrm{N}, 85.86^{\circ} \mathrm{W}\right)$ is located in R4.g in Fig. 4. In this town, tsunami heights between 2.0 and $4.8 \mathrm{~m}$ were observed (Abe et al. 1993). From the numerical computation, the tsunami 


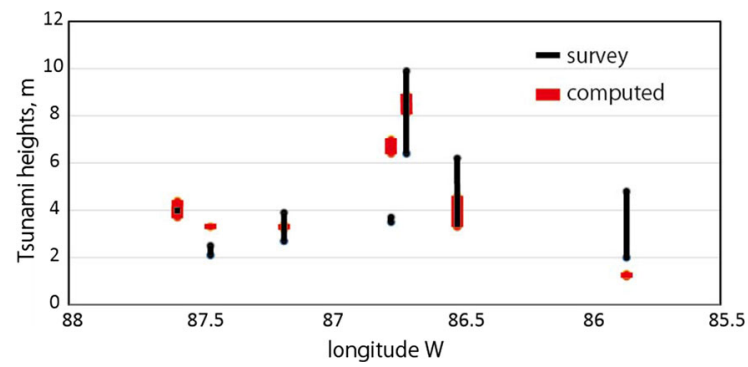

Figure 6

Comparison of the surveyed tsunami heights, black bar, and computed tsunami ones, red bar, at seven locations, Mechapa, Jiquililo, Corinto, Purto Sandino, El Transito, Masachapa, and San Juan del Sur in Fig. 5

heights are estimated between 1.2 and $1.3 \mathrm{~m}$, which are smaller than the observed ones (Fig. $5 \mathrm{~g}$ ). The reason is that the actual fault model for the 1992 Nicaragua earthquake (Satake 1994) was much longer to southeast than the fault model in this study. The maximum inundation distance is calculated to be $110.0 \mathrm{~m}$ from the coastline. The computed inundation depths are less than $0.5 \mathrm{~m}$.

Overall, the tsunami heights and inundation area along the Pacific coast surveyed by Abe et al. (1993) are well explained by the source model with a large slip of $9.6 \mathrm{~m}$ estimated from the result of W-phase inversion and the scaling relationship proposed in this paper as shown in Fig. 6.

\section{The 2001 El Salvador Earthquake (Mw7.7)}

A large earthquake occurred off El Salvador on January 13, 2001. The USGS catalog provides the source parameters: origin time 17:33:32 (UTC); epicenter $13.039^{\circ} \mathrm{N}, 88.660^{\circ} \mathrm{W}$; depth $60 \mathrm{~km}$; magnitude $\mathrm{Mw}$ 7.7. The seismic moment from the GCMT catalog is $3.8 \times 10^{20} \mathrm{Nm}$. This earthquake occurred within the slab with a normal fault type and caused a small tsunami of about $0.25 \mathrm{~m}$ in El Salvador.

\subsection{W-Phase Inversion for the 2001 El Salvador Earthquake}

The vertical components of 125 broadband seismic records shown in Fig. 7 were used for performing the $\mathrm{W}$-phase inversion. Because the earthquake occurred in 2001, there is a much larger number of broadband seismic records than those in 1992. The seismic data are bandpass filtered between 0.00167 and $0.005 \mathrm{~Hz}$. First, the $\mathrm{W}$-phase inversion was carried out using 24 seismic records observed at distances less than $30^{\circ}$. In this distance range, $13 \mathrm{~min}$ of seismic records after the origin time are required for the $\mathrm{W}$-phase inversion. The inversion provided the seismic moment of $4.9 \times 10^{20} \mathrm{Nm}(\mathrm{Mw} 7.7)$, the mechanism $\quad\left(\right.$ strike $=123.3^{\circ}, \quad \operatorname{dip}=24.0^{\circ}$, rake $=-94.2^{\circ}$ ), the centroid location (longitude $88.82^{\circ} \mathrm{W}$, latitude $12.670^{\circ} \mathrm{N}$ ), the centroid depth of $35.5 \mathrm{~km}$, and the half duration of $16.0 \mathrm{~s}$.

Finally, all 125 seismic records observed in the distance less than $90^{\circ}$ were used for the inversion. In this case, 35 min seismic records after the origin time are required. The inversion provided the seismic moment of $4.3 \times 10^{20} \mathrm{Nm}(\mathrm{Mw} 7.7)$, the mechanism $\left(\right.$ strike $=121.0^{\circ}, \operatorname{dip}=29.1^{\circ}$, rake $\left.=-106.6^{\circ}\right)$, the centroid location (longitude $89.13^{\circ} \mathrm{W}$, latitude $12.97^{\circ} \mathrm{N}$ ), the centroid depth of $50.5 \mathrm{~km}$, and the half duration of $16.0 \mathrm{~s}$. We found that the solution is stable, so the seismic records observed at stations in the distances less than $30^{\circ}$ can be used if a rapid response for tsunami early warning is needed.

\subsection{Tsunami Simulation for the 2001 El Salvador Earthquake}

For tsunami simulation, the parameters of final inversion result are used. The length $101 \mathrm{~km}$ and the width $39 \mathrm{~km}$ of the fault model are calculated from Mw7.7 using the scaling relationship of Blaser et al. (2010). The location of the fault model is shown in Fig. 7. The rigidity of $7.0 \times 10^{10} \mathrm{Nm}^{-2}$ for the centroid depth of $50.5 \mathrm{~km}$ is obtained using the depth-dependent rigidity shown in Fig. 2. The slip amount is calculated to be $1.56 \mathrm{~m}$.

Because the observed tsunami was less than $0.25 \mathrm{~m}$, the numerical tsunami simulation solving the non-linear shallow water equations without inundation was carried out. The maximum computed tsunami heights during $6 \mathrm{~h}$ at nine towns, Acajutla, Epino and Union in El Salvador, Cosiguina, Corinto, Sandino, Masachapa, Astillero, and SnFnSur in Nicaragua, are shown in Fig. 7. The observed tsunami of about $0.25 \mathrm{~m}$ is similar to the computed maximum tsunami height of $0.23 \mathrm{~m}$ at Acajutla in El Salvador. 

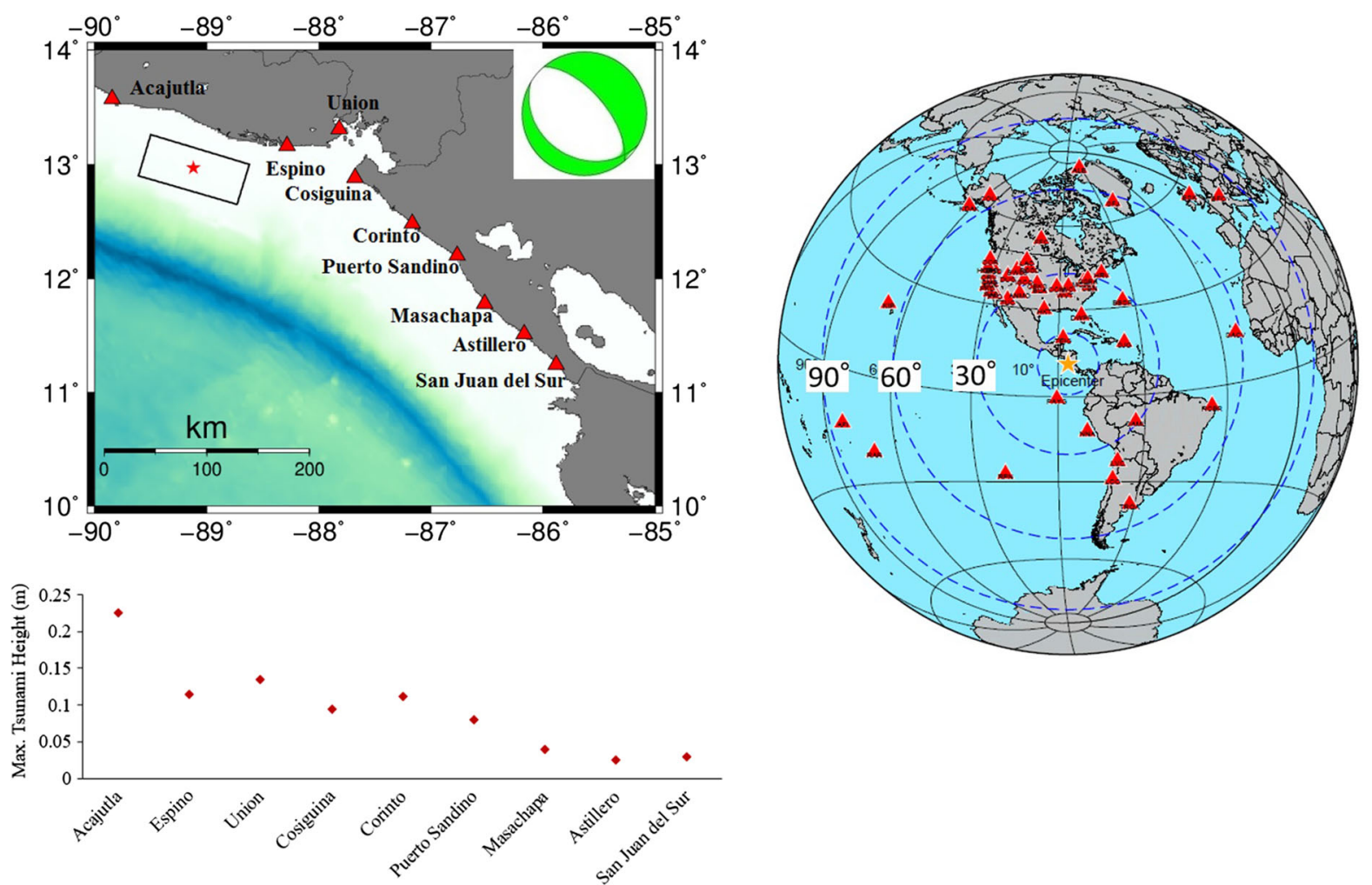

Figure 7

Left upper the fault model and the mechanism of the $2001 \mathrm{El}$ Salvador earthquake estimated from the results of W-phase inversion and scaling relationships. Left lower the maximum computed tsunami heights at nine towns, Acajutla, Epino and Union in El Salvador, Cosiguina, Corinto, Sandino, Masachapa, Astillero, and SnFnSur in Nicaragua. Right the station distribution; red triangles, used in W-phase inversion

\section{The 2004 El Astillero Earthquake (Mw7.0)}

A large earthquake occurred off El Astillero in Nikaragua on October 9, 2004. The USGS catalog provides the source parameters: origin time, 21:26:53 (UTC); epicenter, $11.422^{\circ} \mathrm{N}, 86.665^{\circ} \mathrm{W}$; depth, $34 \mathrm{~km}$; magnitude $\mathrm{Mw}$ 7.0. The seismic moment from the GCMT catalog is $3.0 \times 10^{19} \mathrm{Nm}$. This earthquake occurred at the plate interface, but did not generate an observable tsunami along the coast in Nicaragua.

\subsection{W-Phase Inversion for the 2004 El Astillero Earthquake}

The vertical components of 50 broadband seismic records shown in Fig. 8 were used for performing the $\mathrm{W}$-phase inversion. The seismic data are bandpass filtered between 0.00167 and $0.01 \mathrm{~Hz}$. First, the $\mathrm{W}$-phase inversion was carried out using 15 seismic records observed in distances less than $30^{\circ}$. Finally, all 50 seismic records observed in the distance less than $90^{\circ}$ were used for the inversion.

The first inversion provided the seismic moment of $3.34 \times 10^{19} \mathrm{Nm}$ (Mw 6.9), the mechanism $\left(\right.$ strike $=342.9^{\circ}, \operatorname{dip}=49.1^{\circ}$, rake $\left.=124.3^{\circ}\right)$, the centroid location (longitude $86.918^{\circ} \mathrm{W}$, latitude $11.150^{\circ} \mathrm{N}$ ), the centroid depth of $35.5 \mathrm{~km}$, and the half duration of $12.0 \mathrm{~s}$. The final inversion provided the seismic moment of $3.43 \times 10^{19} \mathrm{Nm}(\mathrm{Mw} \mathrm{7.0})$, the mechanism $\left(\right.$ strike $=314.3^{\circ}, \quad \operatorname{dip}=24.9^{\circ}$, rake $=96.6^{\circ}$ ), the centroid location (longitude $86.510^{\circ} \mathrm{W}$, latitude $11.250^{\circ} \mathrm{N}$ ), the centroid depth of $35.5 \mathrm{~km}$, and a half duration of $13.0 \mathrm{~s}$.

\subsection{Tsunami Simulation for the 2004 El Astillero Earthquake}

For tsunami simulation, the parameters of the final inversion result are used. The length, $36 \mathrm{~km}$, and the width, $22 \mathrm{~km}$, of the fault model are calculated from 

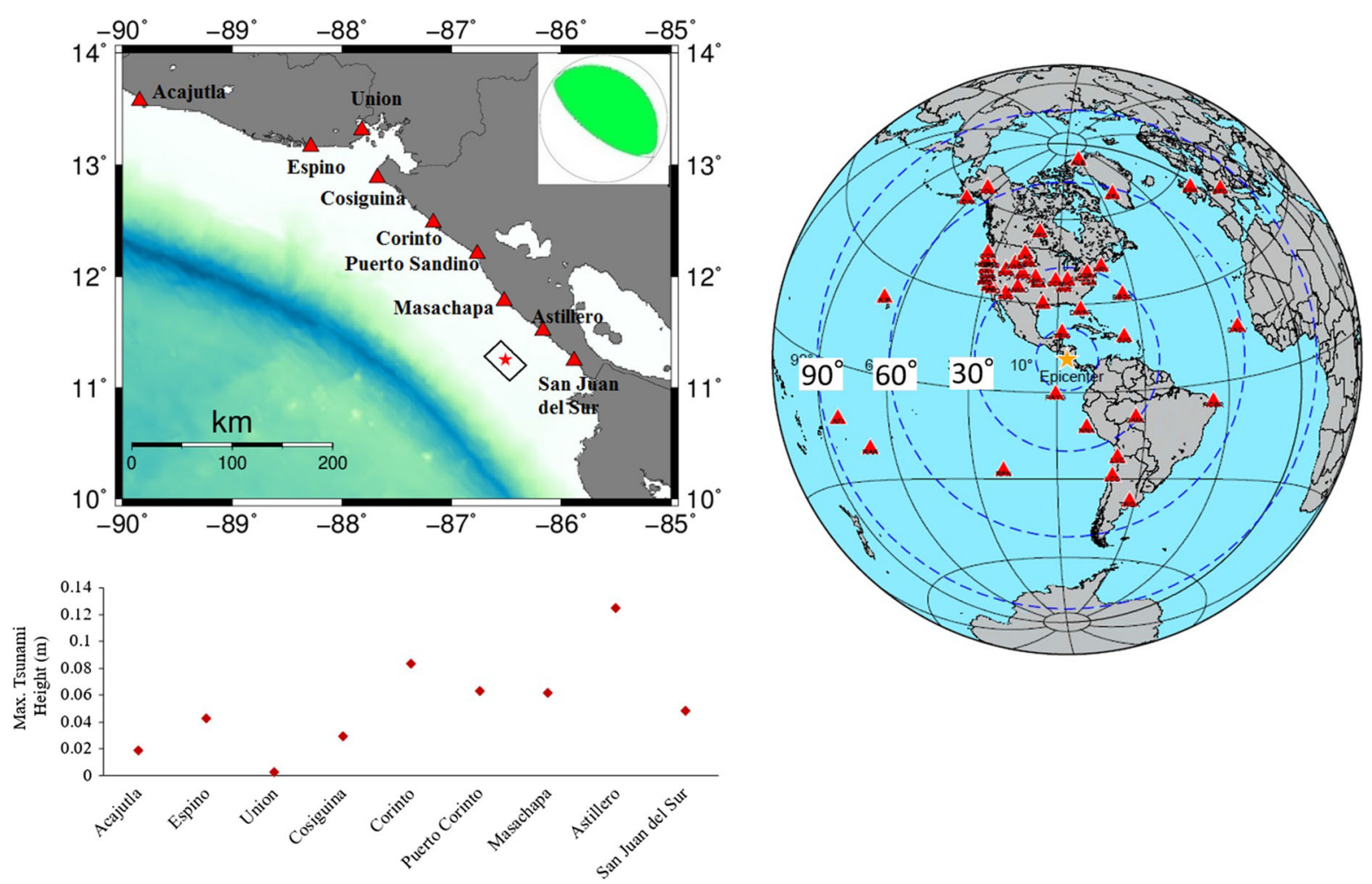

Figure 8

Left upper the fault model and the mechanism of the $2004 \mathrm{El}$ Astillero earthquake estimated from the results of W-phase inversion and scaling relationships. Left lower the maximum computed tsunami heights at nine towns, Acajutla, Epino and Union in El Salvador, Cosiguina, Corinto, Sandino, Masachapa, Astillero, and SnFnSur in Nicaragua. Right the station distribution; red triangles, used in W-phase inversion

Mw7.0 using the scaling relationship of Blaser et al. (2010). The location of the fault model is shown in Fig. 8. The rigidity of $4.0 \times 10^{10} \mathrm{Nm}^{-2}$ for the centroid depth of $35.5 \mathrm{~km}$ is obtained using the depth-dependent rigidity shown in Fig. 2. The slip amount is calculated to be $1.08 \mathrm{~m}$.

The numerical tsunami simulation solving the nonlinear shallow water equations without inundation was carried out. The maximum computed tsunami heights during $6 \mathrm{~h}$ at nine towns are shown in Fig. 8. The maximum computed tsunami heights of $0.12 \mathrm{~m}$ at nine towns are consistent with no observable tsunami along the El Salvador and Nicaragua coast.

\section{The 2012 El Salvador-Nicaragua Earthquake (Mw7.3)}

A large earthquake occurred off El Salvador or Nicaragua on August 27, 2012. The USGS catalog provides the source parameters: origin time, 04:37:19 (UTC); epicenter, $12.139^{\circ} \mathrm{N}, 88.590^{\circ} \mathrm{W}$; depth, $28 \mathrm{~km}$; magnitude $\mathrm{Mw}$ 7.3. The seismic moment from the GCMT catalog is $1.3 \times 10^{20} \mathrm{Nm}$. This earthquake occurred at the plate interface and generated a tsunami with a maximum height of $6.0 \mathrm{~m}$ above sea level (Borrero et al. 2014). Some damages on houses along the El Salvador coast are caused by the tsunami. However, no fatalities were reported. Far-field tsunamis were also recorded at DRAT buoys in the Pacific Ocean (Heidarzadeh and Satake 2014).

\subsection{W-Phase Inversion for the 2012 El Salvador- Nicaragua Earthquake}

The vertical components of 16 broadband seismic records shown in Fig. 9 were used for performing the W-phase inversion. The seismic data are bandpass filtered between 0.00167 and 
$0.01 \mathrm{~Hz}$. First, the W-phase inversion was carried out using six seismic records observed at a distances less than $30^{\circ}$. Finally, all 16 seismic records observed at a distance less than $90^{\circ}$ were used for the inversion.

The first inversion provided a seismic moment of $1.05 \times 10^{20} \mathrm{Nm} \quad(\mathrm{Mw}$ 7.3), the mechanism $\left(\right.$ strike $=311.0^{\circ}, \operatorname{dip}=19.4^{\circ}$, rake $\left.=125.6^{\circ}\right)$, the centroid location (longitude $89.374^{\circ} \mathrm{W}$, latitude $11.820^{\circ} \mathrm{N}$ ), the centroid depth of $15.5 \mathrm{~km}$, and the half duration of $22.0 \mathrm{~s}$. The final inversion provided the seismic moment of $8.73 \times 10^{19} \mathrm{Nm}(\mathrm{Mw} 7.2)$, the mechanism $\quad\left(\right.$ strike $=310.1^{\circ}, \quad \operatorname{dip}=24.9^{\circ}$, rake $=129.7^{\circ}$ ), the centroid location (longitude $89.374^{\circ} \mathrm{W}$, latitude $11.820^{\circ} \mathrm{N}$ ), the centroid depth of $15.5 \mathrm{~km}$, and the half duration of $24.0 \mathrm{~s}$.

\subsection{Tsunami Simulation for the 2012 El Salvador- Nicaragua Earthquake}

For tsunami simulation, the parameters of final inversion result are used. The length, $50 \mathrm{~km}$, and the width, $28 \mathrm{~km}$, of the fault model are calculated from Mw7.2 using the scaling relationship of Blaser et al. (2010). The location of the fault model is shown in Fig. 9. The slip amount is calculated to be $6.15 \mathrm{~m}$ using the rigidity of $1.0 \times 10^{10} \mathrm{Nm}^{-2}$. Numerical computation of tsunami run-up was carried out for two areas, El Retiro (R4.a) and Espino (R4.b) in Fig. 10 where tsunami run-up heights were surveyed by Borrero et al. (2014). Four nested grid systems (R1, R2, R3, and R4 in Fig. 9) are used for this computation.

El Retiro $\left(13.21^{\circ} \mathrm{N}, 88.59^{\circ} \mathrm{W}\right)$ is located on the southwest pacific coast of El Salvador, R4.a in Fig. 10. In this town, tsunami heights between 3.0 and $5.0 \mathrm{~m}$ were observed (Borrero et al. 2014). In our numerical calculation, the tsunami heights are between 2.7 and $3.2 \mathrm{~m}$, slightly smaller than the observed ones (Fig. 11a). The maximum inundation distance is computed to be $203.0 \mathrm{~m}$ from the coastline. The computed inundation depths on this small town are $1.0 \mathrm{~m}$ or less. No damages on houses in this town were reported, because the residents lived $1.0 \mathrm{~km}$ away from the coastline. No fatalities were reported in this town.

Espino $\left(13.16^{\circ} \mathrm{N}, 88.28^{\circ} \mathrm{W}\right)$ is located on the southwest Pacific coast of El Salvador, R4.b in Fig. 10. In this town, there was no measurable tsunami (Borrero et al. 2014). In our numerical simulation, the calculated maximum tsunami height was $1.2 \mathrm{~m}$ (Fig. 11b). The maximum inundation distance is computed to be $190.0 \mathrm{~m}$ from the coastline. No damages on houses in this town were
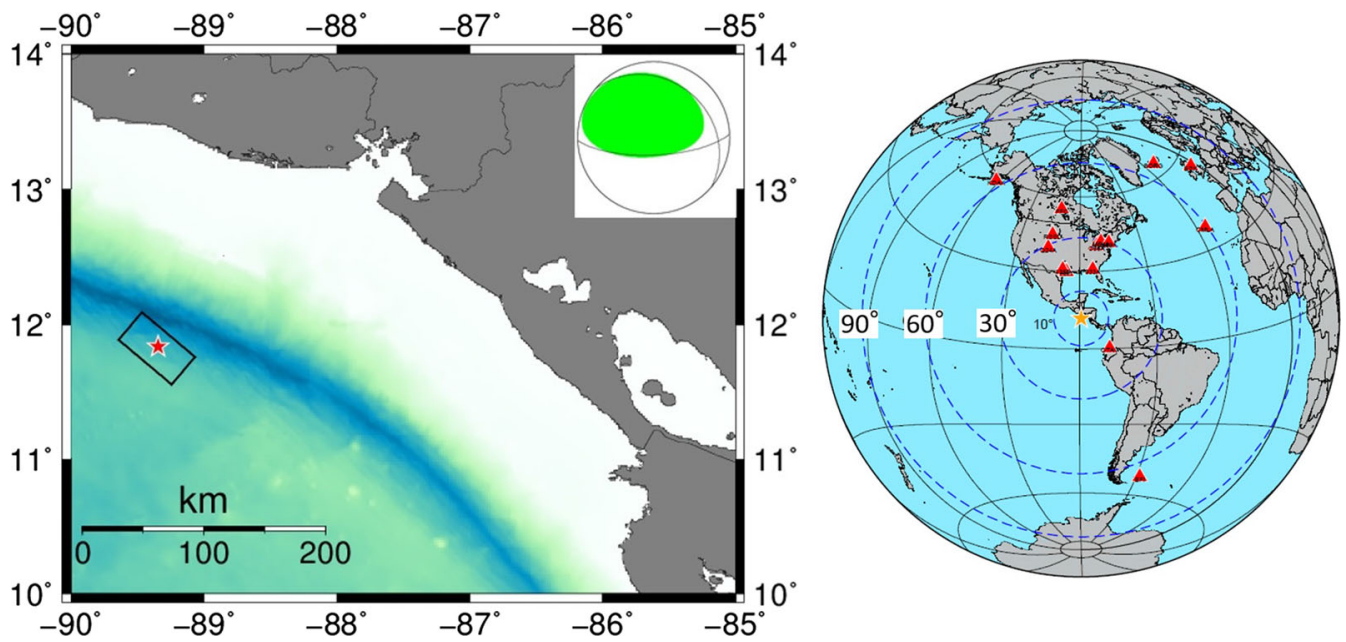

Figure 9

Left the fault model and the mechanism of the 2012 El Salvador-Nicaragua earthquake estimated from the results of W-phase inversion and scaling relationships. Right the station distribution, red triangles, used in W-phase inversion 


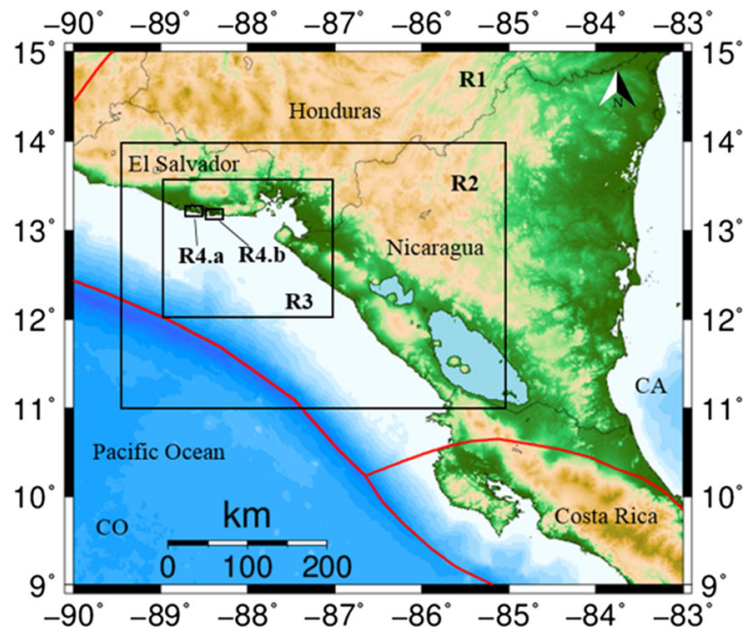

Figure 10

Four nested grid systems $(R 1, R 2, R 3$, and $R 4)$ for the tsunami numerical simulation of the 2012 El Salvador-Nicaragua tsunami. Two areas were selected for tsunami run-up simulation grid systems, El Retiro (R4.a) and Espino (R4.b)

reported, because the residents lived more than $200 \mathrm{~m}$ away from the coastline. No fatalities were reported in this town.

\section{Discussions and Conclusions}

The fault parameters estimated from the W-phase inversion (Kanamori and Rivera 2008) and a scaling relationship (Blaser et al. 2010) with a depth-dependent rigidity (Bilek and Lay 1999) are used to estimate the fault model for four large earthquakes which occurred off El Salvador and Nicaragua in Central America. The tsunami numerical simulations from the above fault models show that the observed tsunami heights, run-up heights, or inundation areas are reasonably well explained by the computed ones. The method was tested for the 1992 Nicaragua tsunami earthquake (Mw7.7), which generated an unusually larger tsunami than that expected from the surface wave magnitude, the 2001 El Salvador earthquake (Mw7.7) occurred in a slab with a normal fault mechanism, the $2004 \mathrm{El}$ Astillero earthquake (Mw7.0) occurred at the plate interface as an underthrust earthquake, and the 2012 El SalvadorNicaragua earthquake (Mw7.3) occurred at the plate interface near the trench. We conclude that the method to estimate appropriate source models of various large earthquakes off Central America worked well for a tsunami early warning purpose.

However, uncertainties of a scaling relationship and a depth-dependent rigidity should be more carefully examined to use the method for a real tsunami early warning. Fast tsunami inundation simulation using a high-performance computing system (Musa et al. 2015) or data-based tsunami inundation forecast (Gusman et al. 2014) are also needed to be combined (a)

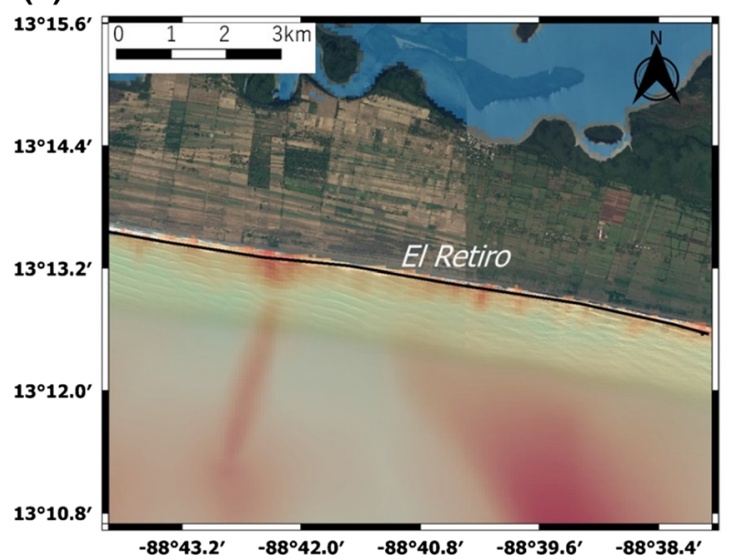

(b)

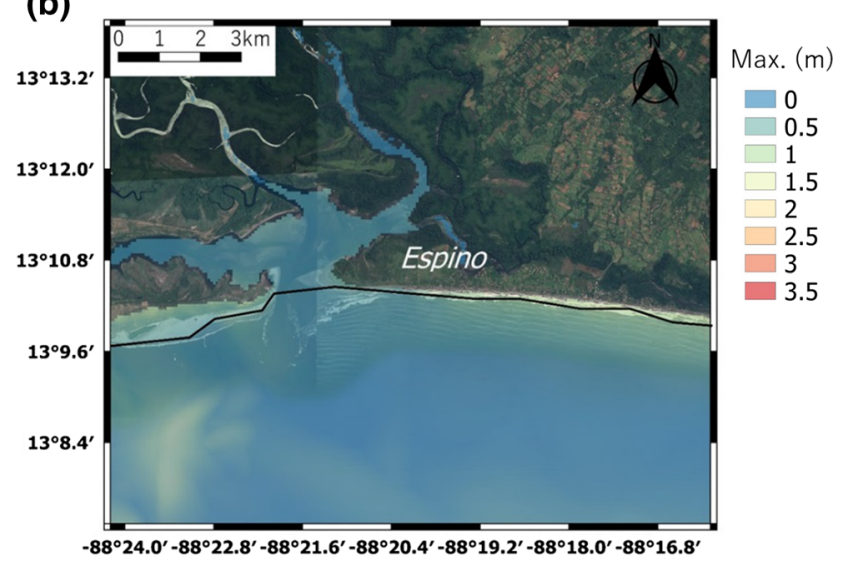

Figure 11

Maximum tsunami height distributions and tsunami inundation area at a El Retiro (R4.a in Fig. 9) and b Espino (R4.b in Fig. 9) computed from the fault model of the 2012 El Salvador-Nicaragua earthquake in Fig. 9 
with the method in this study to provide a real tsunami early warning.

\section{Acknowledgements}

We thank Prof. Kenji Satake and anonymous reviewers for their valuable comments. This study was supported by the Ministry of Education, Culture, Sports, Science and Technology (MEXT) of Japan, under its Earthquake and Volcano Hazards Observation and Research Program.

Open Access This article is distributed under the terms of the Creative Commons Attribution 4.0 International License (http:// creativecommons.org/licenses/by/4.0/), which permits unrestricted use, distribution, and reproduction in any medium, provided you give appropriate credit to the original author(s) and the source, provide a link to the Creative Commons license, and indicate if changes were made.

\section{REFERENCES}

Abe, K., Tsuji, Y., Imamura, F., Katao, H., Iio, Y., \& Estrada, F. (1993). Field survey of the Nicaragua earthquake and tsunami of September 2, 1992. Earthquake Research Institute, University of Tokyo, 68, 23-70. (in Japanese).

Bilek, L., \& Lay, T. (1999). Rigidity variations with depth along interplate megathrust faults in subduction zones. Nature, 400(6743), 443-446.

Blaser, L., Krüger, F., Ohrnberger, M., \& Scherbaum, F. (2010). Scaling relations of earthquake source parameter estimates with special focus on subduction environment. Bulletin of the Seismological Society of America, 100(6), 2914-2926. doi:10.1785/ 0120100111.

Borrero, J. C., Kalligeris, N., Lynett, P. J., Fritz, H. M., Newman, A. V., \& Convers, J. A. (2014). Observations and modeling of the August 27, 2012 earthquake and tsunami affecting El Salvador and Nicaragua. Pure and Applied Geophysics, 171(12), 3421-3435.

Duputel, Z., Rivera, L., Kanamori, H., \& Hayes, G. (2011). Realtime $\mathrm{W}$ phase inversion during the 2011 off the Pacific coast of Tohoku earthquake. Earth Planets Space, 63, 535-539. doi:10. 5047/eps.2011.05.032.

Duputel, Z., Rivera, L., Kanamori, H., \& Hayes, G. (2012). W phase source inversion for moderate to large earthquakes
(1990-2010). Geophysical Journal International, 189, $1125-1147$.

Goto, C., Ogawa, Y., Shuto, N., \& Imamura, F. (1997). IUGG/IOC time project: Numerical method of tsunami simulation with the leap-flog scheme, IOC of UNESCO, manuals and guides 35.

Gusman, A. R., \& Tanioka, Y. (2014). W phase inversion and tsunami inundation modeling for tsunami early warning: case study for the 2011 Tohoku event. Pure and Applied Geophysics, 171(7), 1409-1422.

Gusman, A. R., Tanioka, Y., MacInnes, B. T., \& Tsushima, H. (2014). A methodology for near-field tsunami inundation forecasting: application to the 2011 Tohoku tsunami. Journal of Geophysical Research, 119(11), 8186-8206.

Hanks, T. C., \& Bakun, W. H. (2002). A bilinear source-scaling model for $M-\log A$ observations of continental earthquakes. Bulletin of the Seismological Society of America, 92(5), 1841-1846.

Heidarzadeh, H., \& Satake, K. (2014). The El Salvador and Philippines tsunamis of August 2012: insights from sea level data analysis and numerical modeling. Pure and Applied Geophysics, 171(12), 3437-3455.

Ide, S., Imamura, F., Yoshida, Y., \& Abe, K. (1993). Source characteristic of Nicaraguan tsunami earthquake of September 2, 1993. Geophysical Research Letters, 20, 863-866.

Imamura, F. (1996). Review of tsunami simulation with a finite difference method. In H. Yeh, P. Liu, and C. Synolakis (Eds.), Long-Wave Runup Models (pp. 25-42). World Scientific.

Imamura, F., Shuto, N., Ide, S., Yoshida, Y., \& Abe, K. (1993). Estimate of the tsunami source of the 1992 Nicaragua earthquake from tsunami data. Geophysical Research Letters, 20, 1515-1518.

Kanamori, H., \& Kikuchi, M. (1993). The 1992 Nicaragua earthquake: a slow tsunami earthquake associated with subducted sediments. Nature, 361(6414), 714-716.

Kanamori, H., \& Rivera, L. (2008). Source inversion of W phase: speeding up seismic tsunami warning. Geophysical Journal International, 175(1), 222-238.

Musa, A., Matsuoka, H., Watanabe, O., Murashima, Y., Koshimura, S., Hino, R., Ohta, Y., \& Kobayashi, H. (2015). A realtime tsunami inundation forecast system for tsunami disaster prevention and mitigation. The International Conference on High Performance Computing, Networking, Storage and Analysis (extended abstract).

Okada, Y. (1985). Surface deformation due to shear and tensile faults in a half-space. Bulletin of the Seismological Society of America, 75, 1135-1154.

Satake, K. (1994). Mechanism of the 1992 Nicaragua tsunami earthquake. Geophysical Research Letters, 21, 2519-2522.

Satake, K., Bourgeois, J., Abe, K., Abe, K., Tsuji, Y., Imamura, F., Lio, Y., Katao, H., Noguera, E. \& Estrada, F. (1993). Tsunami field survey of the 1992 Nicaragua earthquake, EOS, pp. $145-157$. 